\title{
DEMOCRACY IN CRISIS
}

\begin{abstract}
This paper takes a look at the current state of Western democracy and the crises looming within it. Financialization of the democratic system, evident in the farreaching influence of well-funded interest groups; emergence of the new media platforms that can sway public opinion almost instantly; the growing influence of digital technology giants due to the vast amount of user data that they possess; the overall influence of the Internet as an abstract entity; the failure of the education system unable to cope with modern day challenges - these are some of the factors that have significantly eroded the Western democracies for the past several decades. The text uses both discourse and content analysis in a complementary way. It is the author's opinion that the factors listed in this paper indicate that Western democratic regimes are likely to transform into some forms of oligarchy, authoritarianism or, most worryingly, ultra-modern manifestations of totalitarianism aided by the array of modern technologies and methods of mass legitimization.
\end{abstract}

\section{Key words}

democracy, crisis, oligarchy, epistocracy, totalitarianism, modernity, financialization, debt, Wolin, Arendt, Brennan, Lazzarato, Habermas, Crouch, Przeworski 
The aim of this paper is to identify some of the factors which upon careful examination may point to the present-day crisis of democracy. It is the author's opinion that this crisis will eventually lead to a permanent transformation of democracy, and the text attempts to examine possible transformation paths as well.

Democracy can be defined on two levels. From the political point of view, it is the process of delegation of power from the people to the governing group via elections. Yet it is also a specific form of self-understanding, an ethical system of worldview, an idea about who and in what way can participate in the distribution of power. This article attempts to present both levels of democracy crisis. The evolution of technology made mass manipulation and persuasion of voters much easier, thus compromising the process of fair and unbiased delegation of power through elections. Ideologically speaking, democracy as a concept of self-rule, participation and ethics has also become problematic due to several factors: (1) the failure to keep economic and political fields separate when one way or another - every level of democratic government is influenced by state debt; (2) the declining power of national states in the age of transnational capital when the economy is global, but democracy remains restricted within the borders of national states; and (3) the seemingly diminishing usefulness of democracy as an idea for the globalized economy and capital to function and profit. Global capital markets are now approaching a point when hybrid or authoritarian political systems are becoming much more attractive in terms of profit.

Democracy seems to be in crisis - an impression which is strengthening with each year and each election in the Western world. This situation may have several roots. (1) Ultramodern ${ }^{1}$ societies are polarized like never before. Arguably, issues that used to be settled through political debate, nowadays seem impossible to solve by using democratic procedures and reaching consensus by meaningful discussions. Such political reality has almost vanished in the age of instant information and social media. It seems today that political opponents merely attempt to vilify each other, presenting their own opinions as the only possible solutions for specific issues and at the same time attempting to disparage their opponents' views. (2) Political ignorance is reaching hitherto unprecedented heights: more and more voters seem to be swayed by their emotions and personal sympathies rather than facts, political programs, or their own socioeconomic

1 The author uses the term "ultra-modern society" to describe the society after the 2008 financial crisis, living in the age of instant information, social media, smart gadgets, accelerated consumerism and conformism. 
interests. (3) The radical left and the radical right have once again attracted significant segments of population. This process is fueled by the perceived inability of the existing political systems to deal with the real issues. As a result, radical activists from both sides use this situation to successfully present their agendas as the only viable remedy for all ills. One might convincingly argue that history is repeating itself; we may again be on the brink of a great war (no matter how it might actually manifest itself) and all this is caused by the fatal failure of the Western democracies to deal with contemporary challenges and heal themselves.

Financialization of the democratic system, visible in the disproportionate influence of well-funded interest groups; emergence of new media platforms that can sway public opinion in an instant; the growing influence of digital technology giants due to the vast amounts of user data they possess; the overall influence of the Internet as an abstract entity; the utter failure of the education system unable to cope with modern-day challenges ${ }^{2}$ - these factors engender the feeling that Western democratic regimes are likely to transform into some forms of oligarchy, authoritarianism or, most worryingly, ultra-modern manifestations of totalitarianism aided by the array of modern technologies and methods of mass legitimization. Modern technologies and new methods of mass legitimization have already played a crucial role in the establishment of totalitarian regimes of the past (Friedrich \& Brzezinski, 1967, pp. 4, 16) and it cannot be excluded that the same will happen again. The transformation of traditional Western systems has already begun, and it would be counterproductive to ignore the threat of totalitarianism: it could disguise itself as a reaction against disintegration of the state; it could become appealing to societies that crave security and stability and thus welcome strong leaders. Furthermore, radical implementation of the concepts of social justice and equality that seem so attractive to the Western world might lead to the rise of ultra-modern totalitarian regimes as well.

2 It is not the aim of this paper to discuss the failures of the modern education system in detail. However, it is no secret that gradual intrusion of business dynamism in the Western educational system has transformed it into marking-, exams-, skills- and profit-oriented system, where societal functions of education have inevitably been marginalized. It has also become highly competitive and polarised, offering much better education to the rich and the able. Young people also seem to be struggling in the digital world of today, as found by the OECD PISA survey for 2018 (OECD, 2019). For more on the impact of the educational system on the society, see e.g. Fareed Zakaria's book In Defense of a Liberal Education (2015). 
One might argue that there is nothing wrong with the need for security and stability, or for social justice and equality. However, these seemingly straightforward concepts can be approached in very radical ways. Modern day conservatives actively use security and stability concerns as the most defining explanation of their stance regarding family and cultural values, immigration, multiculturalism and open border policies. Many political figures that express strong antiimmigrant and conservative views gain immediate, sometimes fanatical support of the conservative public. On the other hand, neo-liberal and neo-leftist political discourse has caused a significant shift in the connotations of the terms "social justice" and "equality". Nowadays social justice is frequently understood specifically as a battle of oppressed minority groups against an oppressor (which in general terms is often described as the Western patriarchy) and a fight for political correctness. The understanding of equality also seems to have changed from the classical "equality of the opportunity" into the notion of "equality of the outcome". The bottom line is that neo-conservatives and neo-leftists seem to have forgotten the lessons of the previous century. As the dramatic events of the 20th century clearly demonstrated, it is impossible to create completely stable, secure, homogenous, equal or just societies without far-reaching and fundamental changes that may lead to violence, necessitate breaking the resistance of opposing groups by force and might even result in complete elimination of entire segments of the population (Aron, 1968, pp. 44-45).

In the modern world, individuals seem to be increasingly detached from family, community and society. It could be supposed that one of the reasons is capitalist dynamism, which praises personal gain and success as the ultimate virtue. Constant promotion of unrestrained consumption also plays a role. This trend seems to create a society consisting of progressively atomized individuals - as well as larger, but still atomized groups of individuals - that are easy to manipulate, persuade and control. Increasingly atomized groups of activists and various minorities are constantly requesting more and more rights for themselves - and only themselves. Ironically, such fragmentation and obsession with privileges was common in the totalitarian regimes of the past. For example, in a true Leninist fashion, the countries of the Soviet bloc had hundreds of artificially created unions and associations representing different professions, each of which was a minority, for example painters, writers, railway workers, firemen, engineers etc. Each such group enjoyed different socioeconomic privileges unavailable to others even though communism was supposed to have abolished privileges and classes. In the same way, today the modern offspring of the Bolshevik doctrine of mobilization - various minority and activist groups - enjoy high levels of 
positive discrimination, quotas, exclusive rights, privileges and vocal political representation, truly giving a fresh meaning to the idea that "all animals are equal, but some animals are more equal than others" (Orwell, 2008, p. 90).

It should be concluded that some of the most evident totalitarian trends in the modern Western world are already quite alarming: atomization of the society, persistent push into overt consumerism, marginalization and demonization of non-mainstream and "politically incorrect" views, forced self-censorship, dismantling of historically established welfare policies, formation of excessively influential financial groups and lobbies, and a very persuasive media propaganda machine. Such totalitarian tendencies seem to be very dangerous in times when an unhealthy fusion of politics and rapid advancement of modern technologies has left large sections of the population unprepared for and defenseless against innovative methods of propaganda and manipulation.

Many modern authors have raised concerns about the alarming developments in Western democracies. Political philosopher Sheldon Wolin claims that the totalitarianism of today is inverted: corporations, private businesses, rich contributors and other groups of economic interest dominate the modern state through political donations, endorsements and lobbying. This contrasts the classical cases of totalitarianism, such as the Soviet Union or Nazi Germany, where the state dominated the economy However, Wolin claims that today it is the economy that dominates the state: the present leaders are not the architects of the system but its products; instead of keeping the masses in a state of constant political mobilization, the system tries to demobilize the society and keep the population in constant political apathy, encouraging them to think that nothing will change. (Wolin, 2008, pp. 41-68).

For example, when the top ten US banks control more than 60 percent of all financial assets of the state and their top personnel is employed at key government advisory positions (Lazzarato, 2012, p. 77), there can be hardly any doubt that economic actors have openly invaded the political and judicial realm, generating instabilities and inequalities and creating an exceedingly imperfect democracy in the US (Mann, 2012, pp. 324, 342). It can be argued that, to some extent, a similar process is occurring in other Western countries.

In his book The Making of the Indebted Man, Maurizio Lazzarato directly states that financialization of the democratic system has gone so far that now we are actually dealing with debt economy, an enormous mechanism created for the sole purpose of managing public and private debt. He claims that this is the most effective system of exploitation that humankind has ever 
seen - a system that has created people who will never finish paying their debts, which are infinite (Lazzarato, 2012, pp. 23, 77).

All the above considerations reveal how much pressure the nation-state-level politicians are under, regardless of the size of the country. They are elected by the majority of the public, which demands stability, security, justice, equality and prosperity. Their election campaigns are funded by financial groups and lobbyists who demand tax cuts, lower public spending, flexible market, and labor policies favorable for investors and big businesses, all of which directly contradicts the demands of the voters who are actually electing politicians. Politicians are also pressured by debt obligations to deterritorialized ${ }^{3}$ financial entities as well as to other nation states, which effectively influences their policies and hinders them from fulfilling promises made to the public. The vocal liberal minority and liberal media, old and new, have lately also gained an upper hand and pressure politicians to clearly express their views on controversial topics such as religion, tolerance, minority rights, and immigration. If the politicians fail to appease the liberal minority and liberal media, or if they have controversial views and lack broad recognition and/or voter base, they can very quickly get marginalized and disappear from the public debate, which effectively minimizes their chances to win elections.

At the same time, radical liberal views, involving blind support of social justice and identity policies, seem to be in some sense backfiring. Since the neoleftist agenda has adopted radical liberal and postmodernist views, divorced from the real-life struggles of the majority of the public, the working class and the middle class are being continually lured in the direction of populist rightleaning movements - hence the overall strengthening of positions by the populist movements in Europe and the US. This leads to stronger polarization and to a reality where it is impossible to have a constructive political dialog, reach consensus and actually deal with the important issues through political discussion.

Democracy and its future has always been an actively debated subject, with significant input coming from Jürgen Habermas and Colin Crouch. For example, the notion of the public sphere as an integral part of democracy, where private and public actors can engage in debates relevant to the public interest, as envisioned in Habermas' works, explains very well the role and impact of the media which right now in the age of new and remarkable technologies have immeasurable influence over the discourse within the public sphere. According

3 The author uses the term "deterritorialized" to emphasize the non-state, offshore and globalized character of such entities. 
to Habermas, the "refeudalization" of power - i.e. intrusion of powerful entities such as giant media conglomerates, transnational corporations as well as state and other political actors into the public sphere - has contributed to the significant decline of the public sphere. The emergence of the Internet and new media has not helped the public sphere as much as expected; it can be argued that the Internet has considerably accelerated the commodification of information and public discourse, while contributing further to the progressive decline of the public sphere.

Another prominent author, Colin Crouch, writes in his book Post-Democracy that even though all democratic institutions are still present and active, the energy and innovative capacity of the political system have shifted to other spheres; namely to the secret discourse between governments and global corporations. This type of post-democracy concept is especially useful in discussions on the financialization of political systems as well as the balance of power between national level democracies and transnational capital.

Democracy is in crisis and we are witnessing its slow decay. What can be done or what level of mobilization is needed to reverse the trend remains undetermined. However, one thing seems clear: the atomization of society, the failing education system, the cultural decadence, the growing political ignorance of voters, the financialization of the democratic system, the invasion of social structures by advanced technologies and new media - all this will slowly but surely lead to a failure of Western democracies. It appears fruitless to hope for a renaissance of democracy in the West. Considering the number of flaws it currently has, it seems unlikely that the system will heal itself and return to the golden age of consensus and pluralism.

Adam Przeworski in his recently published book Crises of Democracy argues that current crises of this system can be traced back to the imposition of the "Washington consensus" led by Margaret Thatcher and Ronald Reagan. He claims that after World War II the political process was concentrated around safety nets guaranteed by government, unions and state-driven capitalism, which made parallel growth of wages and productivity possible. When Reagan and Thatcher mounted an ideological attack on unions and social programs, it led to a fall in union membership, wage stagnation and rapid growth of socioeconomic inequalities. This coordinated attack effectively ended the wealth distribution model, and was followed by decades of political stagnation and economic impoverishment for many layers of society. Przeworski considers that the resulting polarization of the political spectrum made it impossible for opposing parties to reach consensuses and led to many irreversible mistakes 
made by governments in the US and other Western democracies. Over the years these processes gradually undermined the credibility of Western democracies among their disillusioned electorates - and this is the worst part of democratic regression. It slowly erodes trust, democratic ethics and values, sometimes even without a visible attack on democratic institutions. Ultimately such regression may give power to populist authoritarians through fully pluralist and democratic elections.

Currently, the future of Western democratic system is unclear. However, there are possibilities of a viable transformation, with the following three most likely:

1. Oligarchy - transformation of democracy into various forms of oligarchy - in which power rests within a small circle of people - has been an ongoing process for a long time. Nowadays the influence wielded on modern Western democracies by multinational and local financial groups and corporations as well as very rich and powerful individuals is greater than ever. Globalization, consumerism and overall financialization of the democratic system have prepared a fertile soil for oligarchy to thrive, so it has a good chance of becoming the dominant political system in the West. It can be even said that today many states that declare themselves as democracies are in fact functioning oligarchies (Gilens \& Page, 2014, pp. 564-581), where democratic procedures exist merely pro forma, allowing people to choose which political elite will hold the reins of power. However, each new government will face the same temptations, challenges, debt obligations and global actors as the group that ruled before them. It is thus very unlikely that the new political elite will have a choice other than to promote the same policies and solutions; it will probably be susceptible to the same temptations of corruption, elitism and conformism as the elite before them, turning democratic procedures and declarations into a mere device to rotate different political elites in the ruling positions.

2. Epistocracy (rule by citizens with appropriate political knowledge) - as a variation of an enlightened aristocracy, it could be one of the desirable radical changes and possible alternatives to the failing democracy. It means the rule of the knowledgeable, where political power is legally distributed according to skill and competence and where this skill and competence is always checked through a process such as educational and competence-building exercises, related tests and assessments etc. As Jason Brennan argues in his book Against Democracy, "epistocracy has emerged as the main challenger to democracy's throne" (Brennan, 2016, p. 15). 
He thinks that the choice between these two systems is purely instrumental and he strongly argues that epistocracy will outperform democracy and should be implemented without delay. However, Brennan's claim has not been sufficiently proven yet. It is also uncertain how resistant epistocracy will be against the same pressures and temptations that have already corrupted democracy and are unlikely to cease to exist.

3. Some form of totalitarianism - the present polarization of society and acceptance of radical views on both sides of the political spectrum disturbingly evoke the specters of mob rule and totalitarianism described by Hannah Arendt in The Origins of Totalitarianism. Once again, the ranks of populist movements on the left and right are being filled with people who feel marginalized in an increasingly globalized and elitist world. They are calling for strong leaders, strong nations and responsibility on the one hand, and for social justice, rights and radical equality on the other; they distrust the establishment and representative democracy. They prove once again that democracies function with the rules acknowledged only by the minority and tacitly consented to by the masses of indifferent people who, if organized and actively engaged, can completely destabilize functioning democracies (Arendt, 1958, pp. 106-107, 154-156, 312-318). At the same time it should be emphasized that new forms of totalitarianism may not necessarily have the same characteristics as the classic totalitarian regimes of the past. It is very unlikely there will be new concentration camps or Gulags, mass deportations and killings. Nowadays, in order to effectively demonize, marginalize and exclude someone from the public discourse, modern left-wingers do not actually need to send undesirable people to Siberia: it is enough to use mass media and social media criticism, censoring and de-platforming against controversial or so-called politically incorrect individuals or groups. On the other side of the political spectrum, modern right-wingers frequently call for more security, appeal to cultural and national sentiments, and methodically, successfully create an atmosphere of fear not much different from the one that the Gestapo or the KGB sowed and then efficiently harvested and exploited for various purposes. It seems that the range of modern technologies together with new methods of mass legitimization and propaganda provide totalitarian tendencies with an opportunity to flourish in an entirely new setting, but still in a very effective way. It needs to be acknowledged that modern manifestations of right- and left-wing totalitarianism have already inconspicuously mobilized masses and engaged large segments of the population. 
Unfortunately, political and intellectual elites in the West seem to be actively trying to ride the tides of this mass mobilization, exploit and use the alluring power of total organization for political and personal gains, effectively legitimizing the ultra-modern form of totalitarianism.

Out of these three most likely transformations, only one - epistocracy - has a chance to become a publicly debated option, analyzed in legal context, and a choice that the elites and the wider public agree upon. It would most definitely require constitutional changes, large-scale educational campaigns and transformation of political culture. As for oligarchy and forms of totalitarianism, it is entirely possible to imagine that no actual legal changes may be necessary. Democratic procedures like voting, debates and division of power will continue to exist formally, while actual change will happen only in the background. There will be no meaningful political competition; democratic procedures will be maintained as a façade, and the main goal of the ruling elite will be to retain power through manipulated legal procedures or the regular back-and-forth transfer of power between ideologically compatible elites. The difference between a functioning oligarchy and totalitarianism will be found on the conceptual level. In an oligarchy, power will be retained through external means of control and sometimes even with the educated consent of the population if the principles of noblesse oblige are followed by the natural/artificial elites in power ${ }^{4}$. In the modern forms of totalitarianism, classic external means of control like propaganda will be supplemented with internal ones as well. Power will be retained through discourse, indoctrination, thought control and total organization, hence guaranteeing ideological hegemony for the wider political and cultural elites alternating at the seat of power.

\section{REFERENCES}

Arendt, H. (1958). The Origins of Totalitarianism. Cleveland: World Pub. Co. Aron, R. (1968). Democracy and Totalitarianism. London: Weidenfeld \& Nicolson. Brennan, J. (2016). Against Democracy. Princeton: Princeton University Press. Crouch, C. (2004). Post-Democracy. Cambridge: Polity. Friedrich, C., \& Brzezinski, Z. K. (1967). Totalitarian Dictatorship and Autocracy (2nd ed.). New York: Praeger.

4 The author understands a "natural elite" as an elite defined by virtue and talent, whereas "artificial elites" would be defined by wealth and inherited privileges. 
Gilens, M., \& Page, B. (2014). Testing Theories of American Politics: Elites, Interest Groups, and Average Citizens. Perspectives on Politics, 12(3). DOI: 10.1017/ S1537592714001595

Habermas, J. (1991). The Structural Transformation of the Public Sphere: An Inquiry into a Category of Bourgeois Society. Cambridge, Mass: The MIT Press.

Lazzarato, M. (2012). The Making of the Indebted Man. Los Angeles: Semiotext(e).

Mann, M. (2012). The Sources of Social Power: Volume 4, Globalizations, 1945-2011. New York: Cambridge University Press.

OECD. (2019). Young people struggling in digital world, finds latest OECD PISA survey. Retrieved from https://www.oecd.org/education/young-people-struggling-indigital-world-finds-latest-oecd-pisa-survey.htm

Orwell, G. (2008). Animal Farm: A Fairy Story. London: Penguin Books.

Przeworski, A. (2019). Crises of Democracy. Cambridge: Cambridge University Press.

Wolin, S. (2008). Democracy Incorporated: Managed Democracy and the Specter of Inverted Totalitarianism. New Jersey: Princeton University Press.

Young, M. D. (1970). The rise of the meritocracy, 1870-2033: An essay on education and equality. Piscataway, NJ: Transaction Publishers.

Zakaria, F. (2015). In Defense of a Liberal Education. New York, NY: W. W. Norton \& Company. 